\title{
Flood Analysis Using Adaptive Hydraulics (ADH) Model in the Akarcay Basin
}

\author{
Halil Ibrahim BURGAN ${ }^{1}$ \\ Yilmaz ICAGA ${ }^{2}$
}

\begin{abstract}
Every year, thousands of people are loosing their lives and significant financial losses occur because of flood disasters. Floods stem from basin characteristics. Floods can occur due to effects of snow melts and erratic rainfall because of shallow rivers even in summer months in the Akarcay Basin. In this study, Adaptive Hydraulics (AdH) model and The Finite Element Surface Water Modeling System (FESWMS) were used to generate a hydraulic model. Consequently, many settled areas would not face flood risk, but especially agricultural lands in some regions near the banks of streams can experience damages after floods.
\end{abstract}

Keywords: Flood damages, hydraulic modeling, shallow rivers, surface water.

\section{INTRODUCTION}

Flood disaster on a hydrological basin can be predicted by scientific methods. Various modeling techniques are used for the prediction and the prevention studies of flood disaster. These studies covered mathematical, visualization (as 2D/3D mapping etc.) and statistical methods. Also, new Geographic Information System (GIS) technologies are used while producing flood risk maps. Although, hydrological models provide a foresight about flood risk magnitude of a basin, detailed flood risk maps of a basin can be produced by hydraulic models after assessment of the hydrological models. It can be said that hydrological models can be used at basin scale applications and hydraulic models can be used at local scale applications.

Various hydraulic models are used to assess flood risks. Widely used models are exemplifyed as (HEC-RAS, AdH, RMA2 or 4, TUFLOW, MIKE, FLO-2D, IDRISI, SOBEK, FloodWorks, LISFLOOD-FP, TELEMAC-2D, etc.). Surface Water Modeling System (SMS) software comprehends riverine models (e.g. AdH, FESWMS, RMA, TUFLOW) and coastal

Note:

- This paper has been received on April 17, 2018 and accepted for publication by the Editorial Board on October 09, 2018.

- Discussions on this paper will be accepted by May 31, 2019.

- https://dx.doi.org/10.18400/tekderg.416067

1 Istanbul Technical University, Department of Civil Engineering, Istanbul, Turkey - burgan@itu.edu.tr https://orcid.org/0000-0001-6018-3521

2 Afyon Kocatepe University, Dep. of Civil Engineering, Afyonkarahisar, Turkey - yicaga@aku.edu.tr https://orcid.org/0000-0001-9347-4683 
models (e.g. ADCIRC, CGWAVE, CMS, TUFLOW). In this study for the aim of assessing flood risk of the Akarcay Basin, Turkey, AdH and FESWMS models developed by Coastal and Hydraulics Laboratory [1] of US Army Corps of Engineers (USACE) - Engineer Research and Development Center (ERDC) and Brigham Young University (BYU), respectively, were used as the SMS software.

Flood estimations studies can be made by statistical methods as well as visualization methods (as 2D/3D mapping etc.). Statistical methods cover regional flood frequency analysis [2], with a region of influence (ROI) approach and seasonality $[3,4,5]$, with two-component extreme value distribution [6], with historical data [7], with copula method [8] and asymmetric copula [9], Gumbel mixed model [10], classification with basin characteristics [11]. Basically, the statistical modeling occurs by regionalization of gauging stations, the definition of homogenous/similar catchments or transfer of gauged flow data to the catchments which have similar hydrological, meteorological or morphological characteristics. Then, frequency analysis can be used to determine flood discharge corresponding to any return period after the best fit distribution selection of the data and the calculation of selected distribution parameters.

Visualization methods are based on the solutions of 2D or 3D hydrodynamic models, and they are preferable in terms of the presentation of comparable and interpretable results. The usage of them can be in the basin scale as well as local scale. Substantial data with high resolution is required for local scale hydrodynamic modeling. For example, higher than 1:5000 scale digital elevation model (DEM) data is required to be able to extract cross sections of a river. Detailed topography of the watershed was used for the definition of flood risky areas near River Meuse in The Netherlands with a length of $35 \mathrm{~km}, 100 \mathrm{~m}$ width for river with floodplain bed of the river and $3 \mathrm{~km}$ width per cross section [12]. Horritt \& Bates (2002) compared three hydrodynamic models to assess flood risk of Severn River, UK [13]. Sanders (2007) used different on-line DEMs to evaluate flood inundation risks [14]. The acquisition of local DEM data is difficult and also-costly. Besides, the global DEM is freely and easily accessible. Therefore, global DEM as Advanced Spaceborne Thermal Emission and Reflection Radiometer (ASTER), Shuttle Radar Topography Mission (SRTM) and newly Multi-Error-Removed Improved-Terrain (MERIT) with high accuracy, not high resolution by Yamazaki et al. (2017) is widely used in flood risk mapping studies [15].

Shallow waters and lowlands can be affected by flash floods rapidly. Some indices as topographic wetness index or SAGA wetness index or hydrological models can be used for determination of flash flood prone areas. The area of interest of this study is shallow waters and low-lands, so the basin responds in the form of flash floods rapidly to extreme rainfall in winter or snow melts in spring. The investigations support this information for other basins of hydrological similarity. Ciervo et al. (2015) used FLATModel for shallow waters with 1:500 scale topographic maps [16]. Also, Bradford \& Sanders (2002) used Riemann solver for shallow water equations [17]. de Almeida et al. (2016) performed shallow water model with extremely fine-resolution $(10 \mathrm{~cm})$ terrain data for an urban area [18]. Falter et al. (2016) used FLEMOps+r damage model for shallow water areas[19].

There are many applications of FESWMS model. The applications are mostly hydrodynamic models around weir structures and some models for simulation of flow [20], scour analysis $[21,22]$ comparison of HEC-RAS/FESWMS flood risk boundaries [23], habitat restoration and sediment transport [24, 25, 26], park restoration [27], sedimentation and scour in small urban lakes [28], habitat model [29], river bifurcation analysis [30]. 
The second hydrodynamic model was used as AdH model in this study. The AdH model is newly developed and is shared openly with users. The model has a very wide range of usage, and leads to very innovative applications and satisfactory results. Some of the applications are modeling of floating objects [31], surge overtopping of a levee [32], groundwater [33], the effects of shoreline sensitivity on oil spill trajectory [34], complex river-lake interactions [35], the effects of the surge protection structure on Gulf Intracoastal Waterway [36], habitat restoration and flood control protection [37], navigation lock filling system and mass conservation [38, 39], transient simulation [40], hydrologic model at watershed scale [41], dam and levee breach [42].

Peak flood discharge or flood hydrograph is required as an input in the hydraulic model. It can be acquired from observed flow data of gauging station on the stream. However most of the time, it is not possible to find gauging stations on the river. In this case, synthetic hydrograph methods can be used. In this study, for the observed flow data from State Hydraulic Works in Turkey, Mockus method, SCS method and linear regression between rainfall and discharge data were used to acquire peak flood discharge.

\section{METHODS}

In the first step of this work, the determination of peak flood discharges, which were used in the models, consisted of three methods. Firstly, observed monthly flow data (hydrographs) from gauging stations was assessed. Then, Synthetic methods, SCS \& Mockus, to estimate peak flood discharges were used. Finally, rainfall-runoff relationship was investigated using observed monthly total precipitation data.

In the final step, hydrodynamic models, AdH and FESWMS models were run using peak flood discharge and DEM data. The most important advantage of the selected hydrodynamic models is that they provide good results in shallow water modeling as in the case of Akarcay Basin rivers.

\subsection{SCS Method}

SCS method has very simple and easy methodology to estimate peak flood discharge based on basin morphological parameters. The method provides close results to the observations. The required parameters basically were calculated. The time of concentration, $t_{c}(\mathrm{~h})$ is found by Kirpich equation:

$t_{c}=0.066\left(\frac{L^{2}}{S}\right)^{0.385}$

In which $L$ is the length of the drainage channel $(\mathrm{km}), S$ is average slope of drainage area (\%). The total duration of rainfall, is $D(\mathrm{~h})$ :

$D=0.133 t_{c}$

Time of peak, $t_{p}(\mathrm{~h})$ : 
$t_{p}=\frac{D}{2}+0.6 t_{c}$

Then Curve Number $(\mathrm{CN})$ is found according to soil moisture capacity from SCS-CN table. The potential maximum retention, $S^{\prime}(\mathrm{mm})$ :

$S^{\prime}=\frac{1000}{C N}-10$

The maximum flow height, $h_{e}(\mathrm{~mm})$ :

$h_{e}=\frac{\left(h_{a}-1\right)^{2}}{\left(h_{a}-1+S^{\prime}\right)}$

where $h_{a}$ is annual rainfall depth of selected return period (mm). Then, peak discharge, $Q_{p}$ $\left(\mathrm{m}^{3} / \mathrm{s}\right)$ :

$Q_{p}=0.2083 \frac{A}{t_{p}} h_{e}$

where drainage area, $A\left(\mathrm{~km}^{2}\right)$.

\subsection{Mockus Method}

Triangular hydrograph is produced by the Mockus method. It can be applied easily for defining flood hydrograph. Also this method considers the basin shape factor, $R_{d}$ :

$R_{d}=\frac{A}{A^{\prime}}$

where $A^{\prime}\left(\mathrm{km}^{2}\right)$ is the smallest circle area which covers drainage boundary. The time of concentration, $t_{c}(\mathrm{~h})$ is calculated by the Kirpich formula (Eq. 1) if $R_{d}$ is between 0.6-0.7 then the basin shape is assumed to be circular. Time of peak, $t_{p}(\mathrm{~h})$ :

$t_{p}=\sqrt{t_{c}}+0.6 t_{c}$

The unit peak discharge, $q_{p}\left(\mathrm{~m}^{3} / \mathrm{s} \mathrm{mm}\right)$ :

$q_{p}=0.208 \frac{A}{t_{p}}$

Peak discharge, $Q_{p}\left(\mathrm{~m}^{3} / \mathrm{s}\right)$ :

$Q_{p}=q_{p} h_{a}$

where annual rainfall depth of selected return period, $h_{a}(\mathrm{~mm})$. 


\subsection{Rainfall-Runoff Relationship for Peak Flood Discharge}

The nonlinear regression method is applied to monthly peak discharge, $Q_{p}\left(\mathrm{~m}^{3} / \mathrm{s}\right)$, drainage area, $A\left(\mathrm{~km}^{2}\right)$ and monthly total precipitation data, $P(\mathrm{~mm})$. The regression equation for peak discharge, $Q_{p}\left(\mathrm{~m}^{3} / \mathrm{s}\right)$ :

$Q_{p}=3.7141(A . P)^{0.1358}$

\section{STUDY AREA}

Akarcay Basin is located between $30^{\circ}-32^{\circ}$ east longitudes (240000-400000 UTM) and $38^{\circ}$ $39^{\circ}$ north longitudes (4210000-4330000 UTM). The basin is the second large closed basin in Turkey with $7340 \mathrm{~km}^{2}$ drainage area. The basin has boundaries with the Aegean, Mediterranean and Central Anatolia geographical regions of Turkey. Due to its geographical location, it has characteristics of depression plain and impermeable soil layer. In the basin, erratic rainfall causes extreme events. In consequence of this erratic rainfall, increasing amount of water can cause flash floods in some rivers during winter and some rivers can run dry due to the decreasing amount of water during summer months. There are two natural lakes Lake Eber and Aksehir (Figure 1). They have rich living species. Hydrological studies have great importance because source of income where local people lives is provided by agriculture and animal husbandry. Also, the closed basin is fed by groundwater resources. Gazligol and Afyonkarahisar which have main settlements developed due to thermal water (SPA's) and health tourism [43].

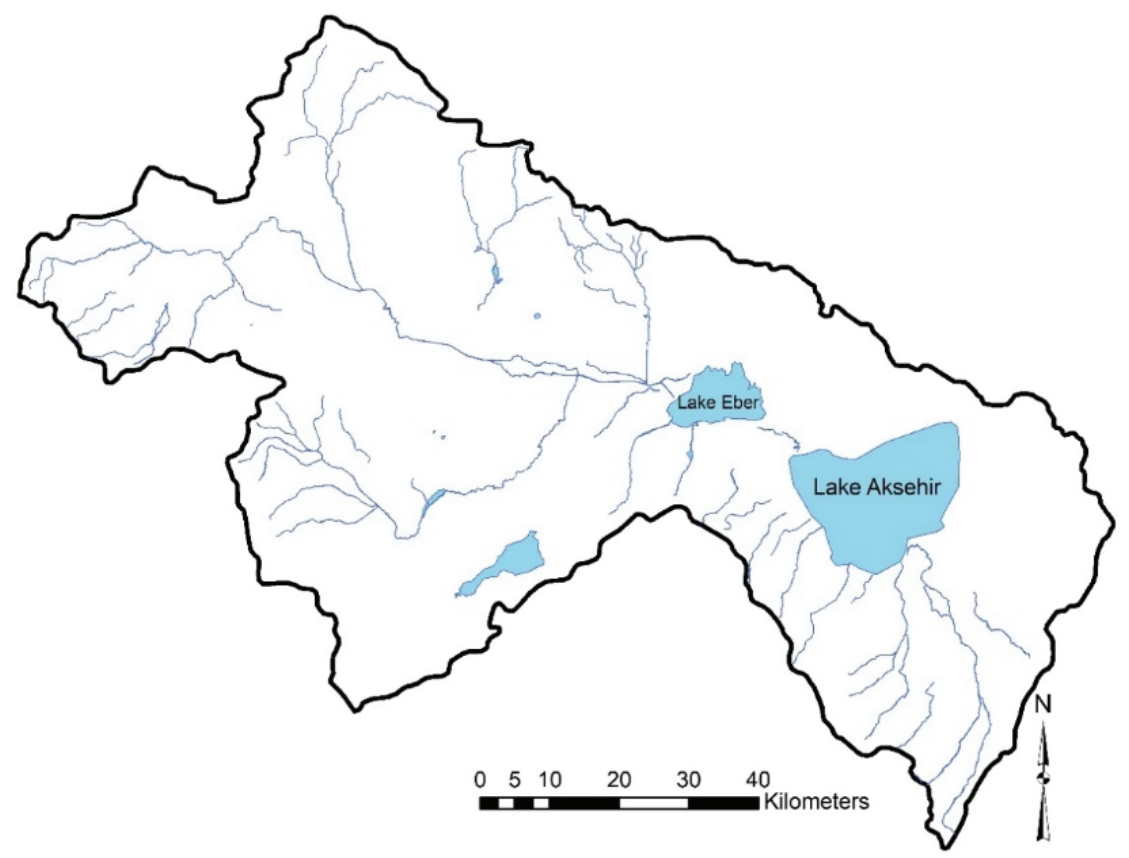

Figure 1 - Location map of Akarcay Basin 


\section{DATA}

Topographical data used in this study were obtained from the General Directorate of Mapping, Turkey in the form of 1/25000 scaled 107 maps. Area properties were derived from maps in raster format. The Manning's roughness coefficients $(n)$ of each area are presented in Table 1. Forested areas have higher Manning's roughness coefficients than urban areas. Also, the coefficients of river bed and highway are very close to each other and attain minor values. In these parts, flow velocity is high because of impermeable layer and less roughness. It is known that most of rivers and shallow waters in the watershed have natural cross sections and bed form. But the water level changes in the rivers are affected by anthropogenic impacts such as irrigation for agriculture. Synthetic flood hydrograph methods were used to be able to eliminate these impacts and determine flood discharge. 1/5000 high scaled 6 maps were taken from the General Directorate for Land Registry and Cadastre, Turkey for the University Campus of Afyon Kocatepe which is flash-flood prone due to high groundwater level. In addition, it was observed that the campus has high soil moisture and flow accumulation increases after any heavy rainfall event. At the same time, most of the campus area is known to be marshy area. The highway in front of the campus plays a very important role for transportation and connection between Afyon-Eskisehir cities and Gazligol County, which has a large capacity in terms of thermal water and health tourism. The high detailed maps were in the paper format, so they were digitalized using the GIS modeling technique.

Turkish Ministry of Forestry and Water Management provides geographically some environmental data by online access but not downloadable from geodata application. The data on the basin boundaries, gauging station locations, forests, highways, railways, river lengths, water bodies, water storage structures such as dams, hydraulic structures, bathymetry, administrative boundaries, etc. were accessible.

Table 1 - The selected Manning's roughness coefficients (n) in the study area [44]

\begin{tabular}{ll} 
Area & $n$ \\
\hline River & 0.03 \\
Forest & 0.10 \\
Light forest & 0.08 \\
Highway and railway & 0.02 \\
Other & 0.06
\end{tabular}

Hydrological data was taken from the State Hydraulic Works (DSI) of Turkey. The observed data is obtained by annual instantaneous maximum discharge and monthly mean discharge in $\mathrm{m}^{3} / \mathrm{s}$ (Figure 2). The calibration process for flood discharges was provided by annual instantaneous maximum discharge. Some gauging stations of the rivers in Akarcay Basin were compared with their minimum discharges and they are classified by intermittent and non-intermittent rivers. Figure 3 demonstrates the maximum water levels change in $1-1.5 \mathrm{~m}$ and confirms that the basin has shallow waters. 


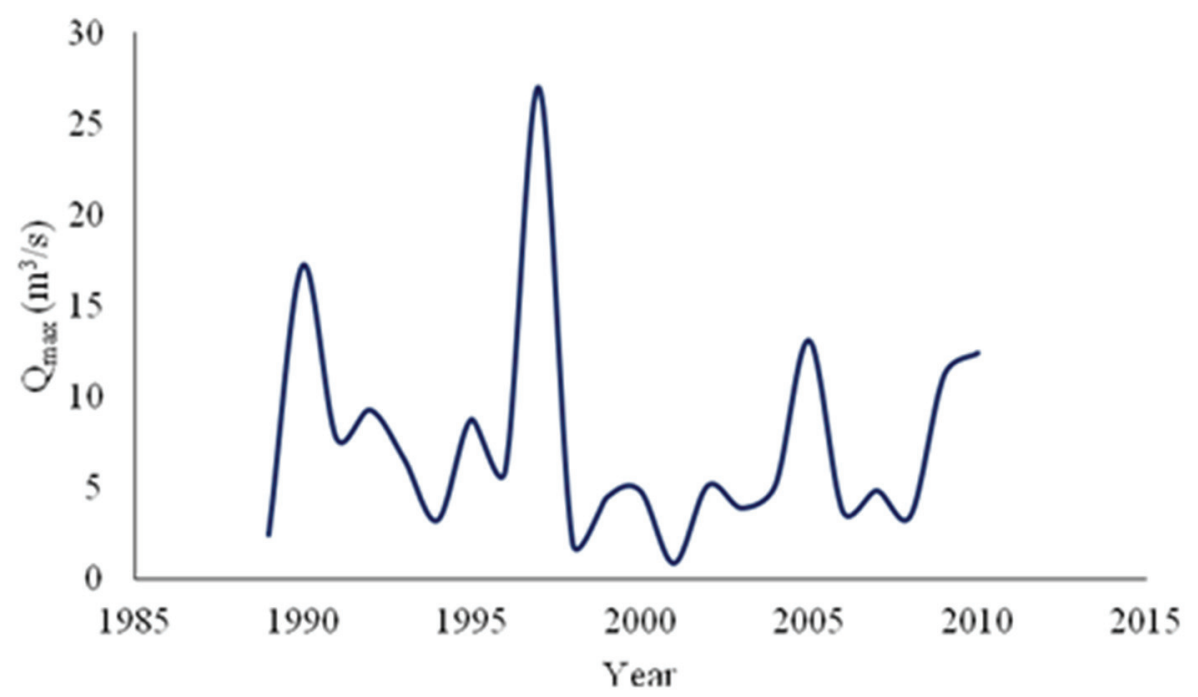

Figure 2 - Annual instantaneous maximum discharge of D11A021 gauging station

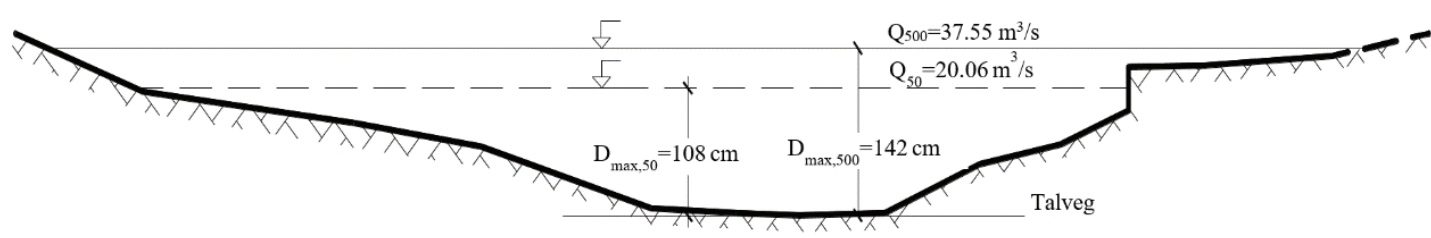

Figure 3 - The cross section at the point of D11A024 gauging station

Meteorological data were taken from the General Directorate of Meteorology (MGM). Monthly total precipitation, evaporation and temperature data were evaluated while investigating rainfall-runoff relationship. Only monthly total precipitation data was considered because the cause of flash floods is based on snow melting and heavy rainfall during spring season in the basin.

\section{MODEL APPLICATIONS}

Two hydrodynamic models were used to assess flood risk in Akarcay Basin. DEM data was prepared for the purpose of use in software. Then, area properties were extracted as a polygon from 1/25000 scaled digital maps in shapefile format. FESWMS and AdH models solve the flow equations using the finite element method. They are separated by mesh type as 8-node or 9-node quadrilateral (FESWMS) and 6-node triangle (AdH). The boundaries of river and floodplains were constructed in the software (Figure 5). The peak flood discharges are presented as input in the models (Table 2). Calculated peak flood discharges are in the 100year return period. 


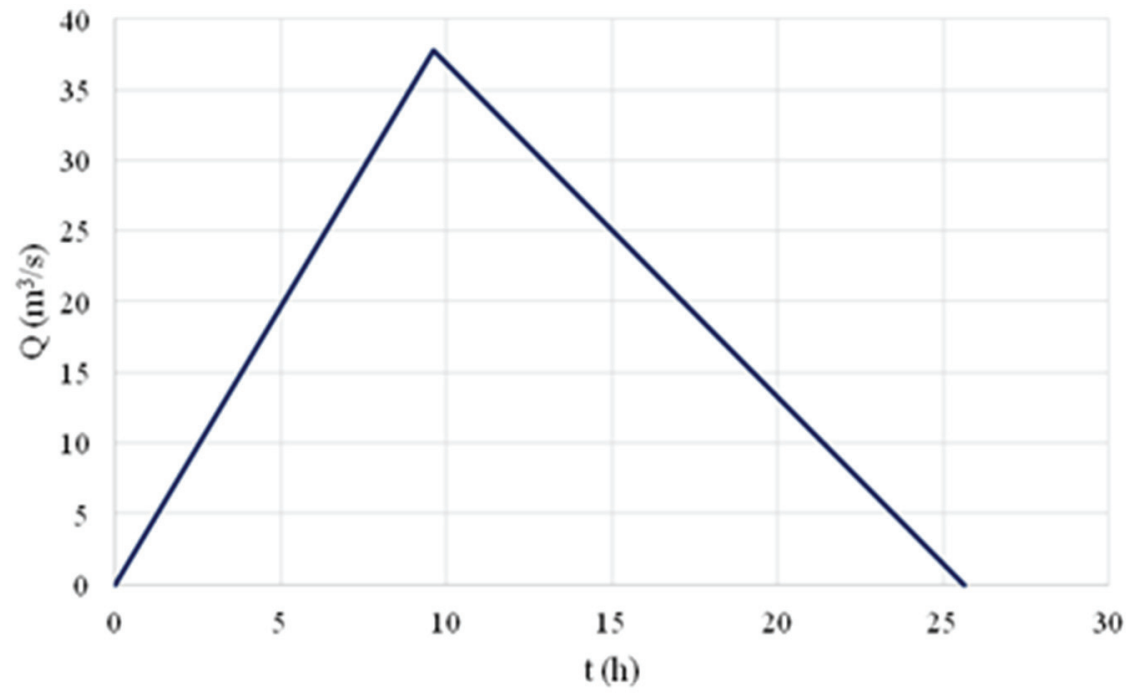

Figure 4 - The triangular Mockus flood hydrograph at the inlet of Akarcay Basin

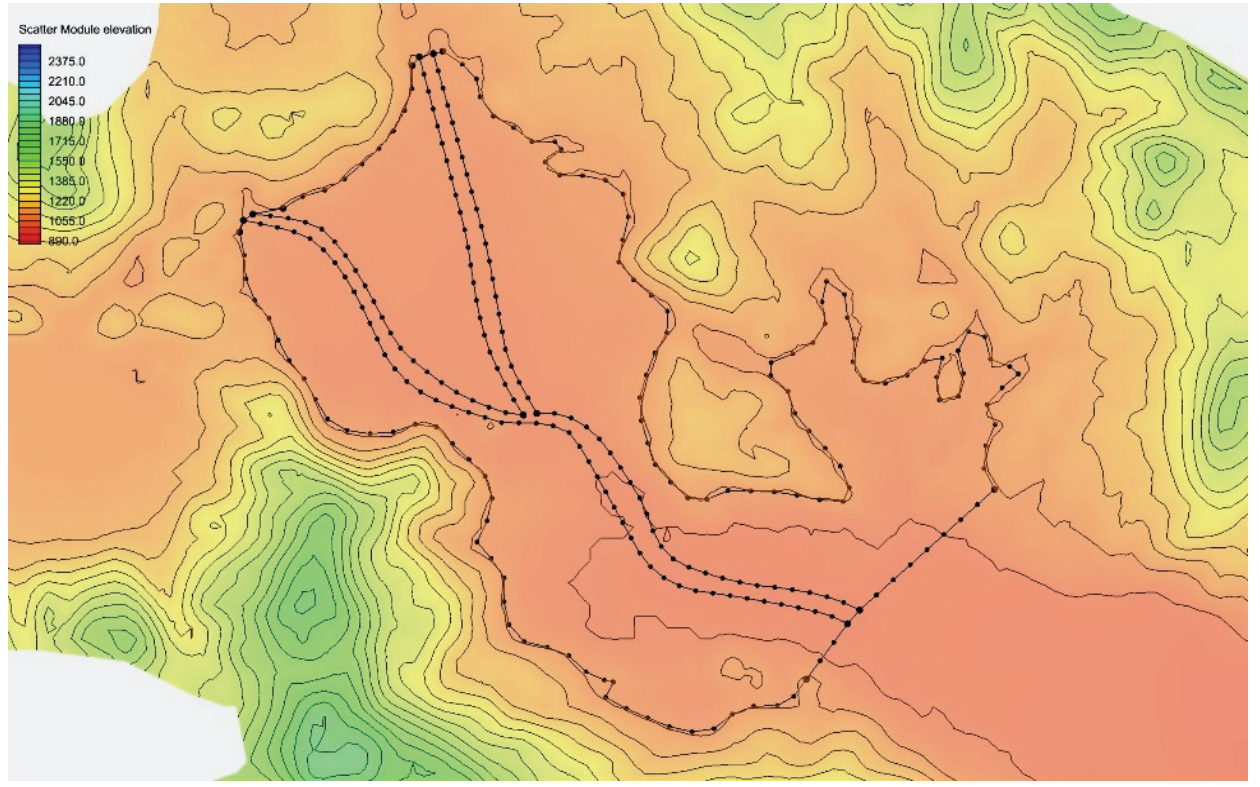

Figure 5 - Boundary conditions for inlets and outlet of the Akarcay Basin

Time of peak, $t_{p}$ is calculated from Eq. (8) as $9.6 \mathrm{~h}$. Time of peak and recession time of flood hydrograph are summed up for the aim of finding the base time of the flood hydrograph. The triangular Mockus flood hydrograph is demonstrated in Figure 4. 
Table 2 - Observed and calculated peak flood discharges

\begin{tabular}{ll} 
Method & $\mathrm{Q}\left(\mathrm{m}^{3} / \mathrm{s}\right)$ \\
\hline Observed & 32.60 \\
SCS & 80.82 \\
Mockus & 37.82 \\
Regression & 29.65
\end{tabular}

\subsection{FESWMS Model}

FESWMS model runs under supercritical and subcritical flow regimes. Also, this model can be used to simulate flow in rivers and floodplains where vertical velocities are small in comparison to horizontal velocities, using wetting-drying conditions. FESWMS solves the following equations simultaneously:

$\frac{\partial z_{w}}{\partial t}+\frac{\partial q_{1}}{\partial x}+\frac{\partial q_{2}}{\partial y}-q_{m}=0$

$\frac{\partial q_{1}}{\partial t}+\frac{\partial}{\partial x}\left(\frac{q_{1}^{2}}{d}+\frac{1}{2} g d^{2}\right)+\frac{\partial}{\partial y}\left(\frac{q_{1} q_{2}}{d}\right)+g d \frac{d z_{b}}{\partial x}+g n^{2} \frac{q_{1} \sqrt{q_{1}^{2}+q_{2}^{2}}}{d^{7 / 3}} \sqrt{1+\left(\frac{d z_{b}}{\partial x}\right)^{2}+\left(\frac{d z_{b}}{\partial y}\right)^{2}}-$

$2 d \varepsilon_{x x} \frac{\partial^{2} \bar{u}}{\partial x^{2}}-\varepsilon_{x y} \frac{\partial}{\partial y}\left(\frac{\partial \bar{u}}{\partial x}+\frac{\partial \bar{v}}{\partial y}\right)=0$

$\frac{\partial q_{2}}{\partial t}+\frac{\partial}{\partial x}\left(\frac{q_{1} q_{2}}{d}\right)+\frac{\partial}{\partial y}\left(\frac{q_{2}^{2}}{d}+\frac{1}{2} g d^{2}\right)+g d \frac{d z_{b}}{\partial y}+g n^{2} \frac{q_{2} \sqrt{q_{1}^{2}+q_{2}^{2}}}{d^{7 / 3}} \sqrt{1+\left(\frac{d z_{b}}{\partial x}\right)^{2}+\left(\frac{d z_{b}}{\partial y}\right)^{2}}-$

$2 d \varepsilon_{y y} \frac{\partial^{2} \bar{v}}{\partial y^{2}}-\varepsilon_{y x} \frac{\partial}{\partial x}\left(\frac{\partial \bar{u}}{\partial x}+\frac{\partial \bar{v}}{\partial y}\right)=0$

where Eq. (12) is the continuity equation and Eqs. (13) and (14) are momentum equations in $x$ and $y$ directions, respectively. In the equations, $t=$ time $(\mathrm{s}) ; d=$ water depth $(\mathrm{m})$; $g=$ acceleration due to gravity $\left(\mathrm{m} / \mathrm{s}^{2}\right) ; z_{w}$ and $z_{b}=$ water surface elevation and bed elevation above certain datum (m); $q_{1}$ and $q_{2}=$ unit discharge fluxes $\left(\mathrm{m}^{2} / \mathrm{s}\right)$ defined as $\bar{u} d$ and $\bar{v} d$, respectively; $\bar{u}$ and $\bar{v}(\mathrm{~m} / \mathrm{s})=$ depth-averaged velocities of an element in the streamwise and transverse directions, respectively; $q_{m}=$ resultant inlow or outflow from that element $(\mathrm{m} / \mathrm{s})$; $\varepsilon_{x x}$ and $\varepsilon_{y y}=$ normal components of the eddy viscosity $\left(\mathrm{m}^{2} / \mathrm{s}\right)$ in the $x$ and $y$ directions, respectively; and $\varepsilon_{x y}$ and $\varepsilon_{y x}=$ shear components of the eddy viscosity $\left(\mathrm{m}^{2} / \mathrm{s}\right)$ applied to the $x-y$ plane.

Initial and boundary conditions were determined in the model. Water surface elevation for the outlet and peak flood discharge for the inlets were determined as shown in Figure 6 . The required other parameters as Eddy viscosity coefficients $\left(V_{o}\right) 100$ and 50 for land and river, respectively. The coefficient is used to define turbulence characteristics. So, Eddy viscosity coefficient is higher in floodplain areas than the river. Wind and wave effects weren't considered because of insufficient data. Under steady flow, the user inputs are boundary conditions a discharge upstream and a stage downstream. The model calculates stages 
throughout the interior points, keeping the discharge constant. Under unsteady flow, the user inputs a discharge hydrograph at the upstream boundary and a discharge-stage rating at the downstream boundary. The model calculates discharges and stages throughout the interior points. All scenarios were applied under steady state case assuming constant flood discharge. The boundary conditions were determined according to flood discharges and dry conditions were taken into consideration considering that the rivers in the basin are dry during certain periods of the year for the initial conditions.

For the aim of flood modeling of the basin, FESWMS model was used in the whole of the Akarcay Basin and AdH model was used for the subbasins of Akarcay Basin with $80.82 \mathrm{~m}^{3} / \mathrm{s}$ peak discharge, which is found by SCS method against 100 -year return period. Flood propagation with FESWMS model is demonstrated by Figures 7-10. Flood propagation is examined in regard of 4 different places (Afyon, Bolvadin, Cay, Suhut) altitudes for the aim of determination as water level thresholds (Figures 7-10). Altitude affects the flooded area's forward propagation. When the altitude increases, the flooded area increases and vice versa. Flooded areas are calculated as 503.96, 422.13, 1126.16 and $1596.61 \mathrm{~km}^{2}$. Mesh modules are defined as water levels during flood event. Flow velocities and magnitudes are demonstrated by Figure 11. The flow velocities are calculated taking into consideration Suhut (highest altitude) threshold. The maximum velocity is calculated as $1.91 \mathrm{~m} / \mathrm{s}$ in the Akarcay Basin.

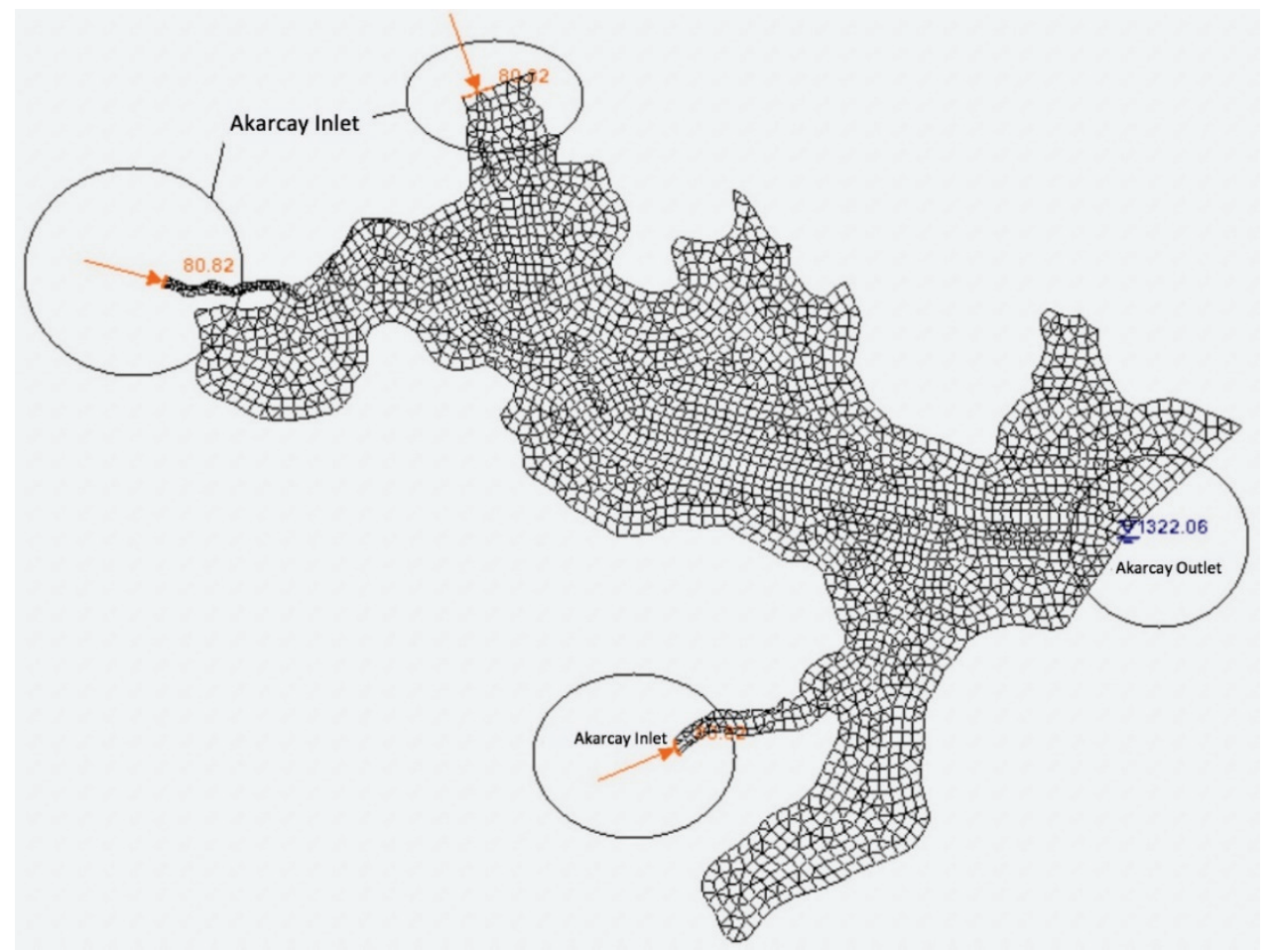

Figure 6 - Boundary conditions for inlets and outlet of the Akarcay Basin 


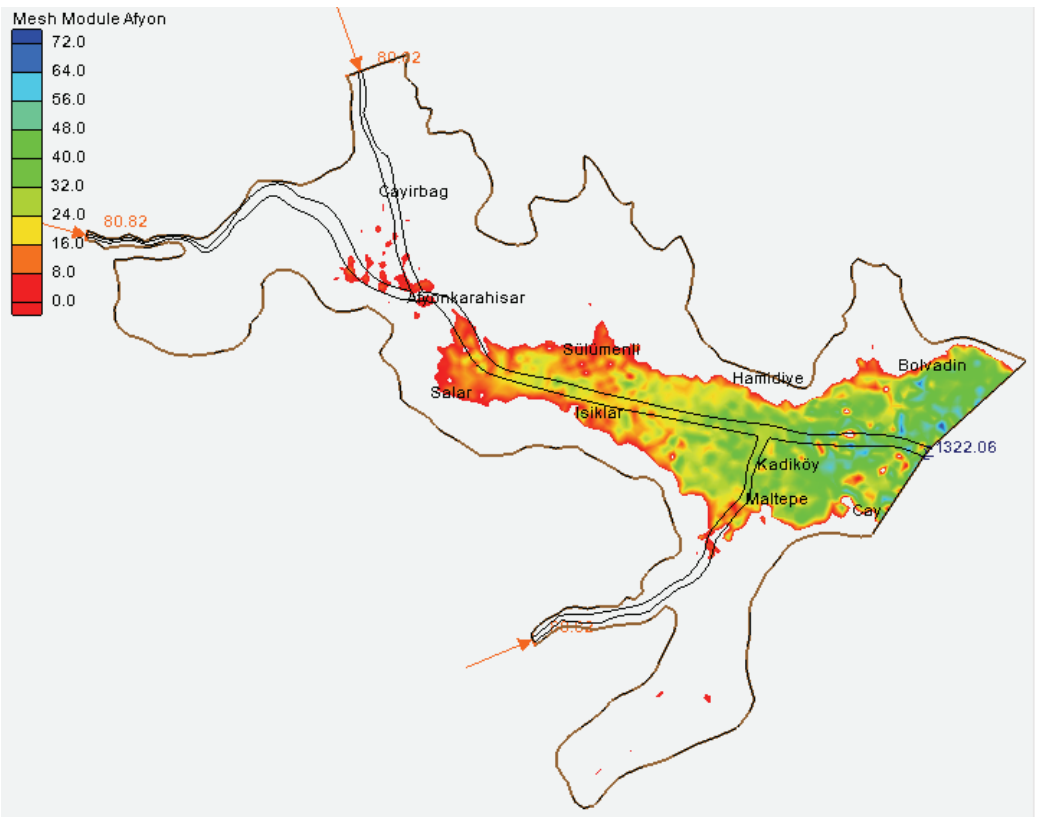

Figure 7 - Flood risk map of the Akarcay Basin in FESWMS model according to altitude of Afyon in threshold

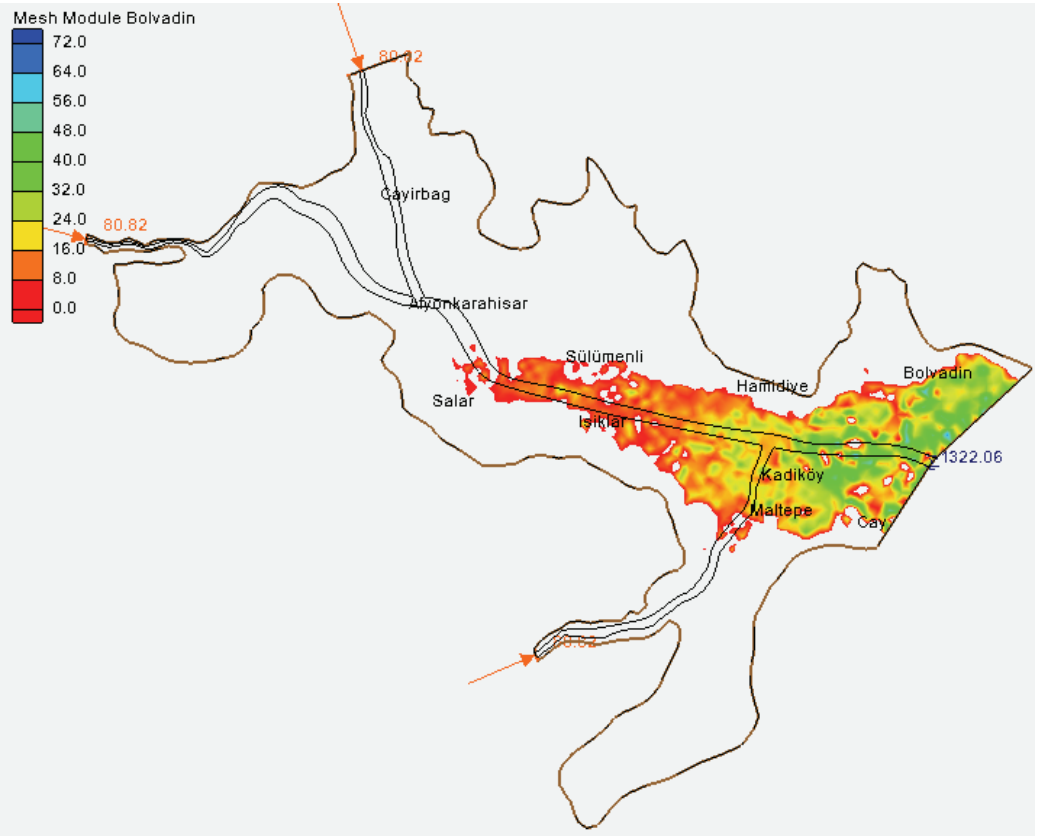

Figure 8 - Flood risk map of the Akarcay Basin in FESWMS model according to altitude of Bolvadin in threshold 


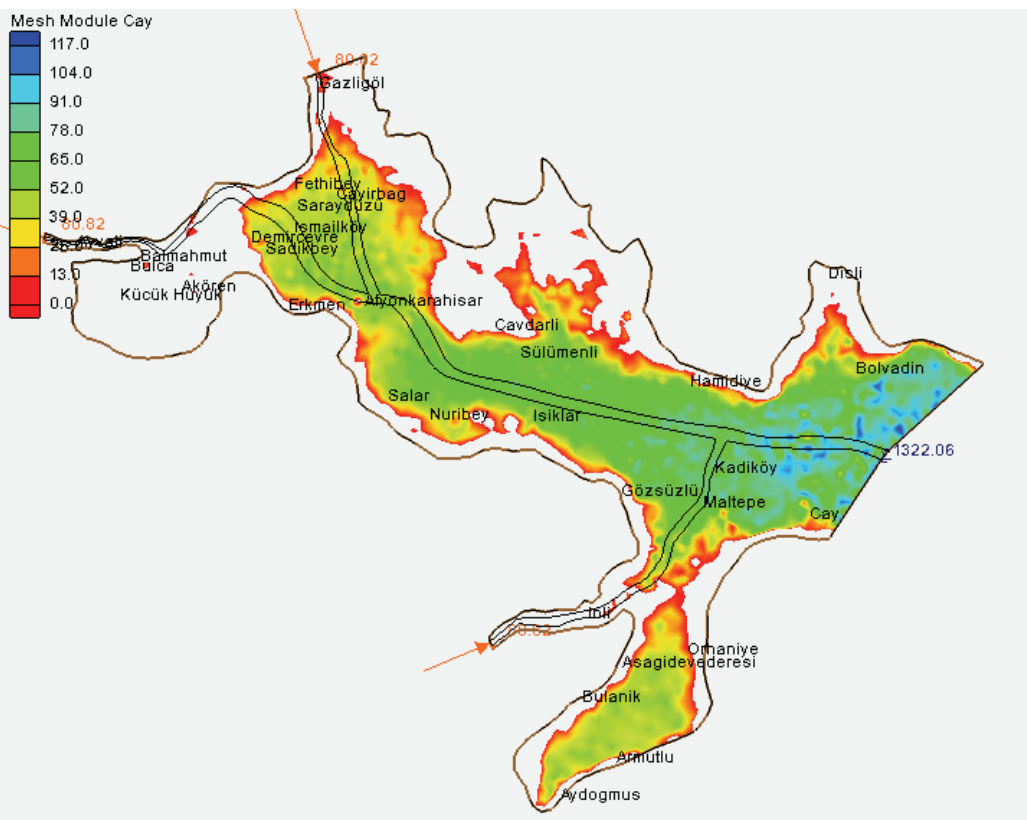

Figure 9 - Flood risk map of the Akarcay Basin in FESWMS model according to altitude of Cay in threshold

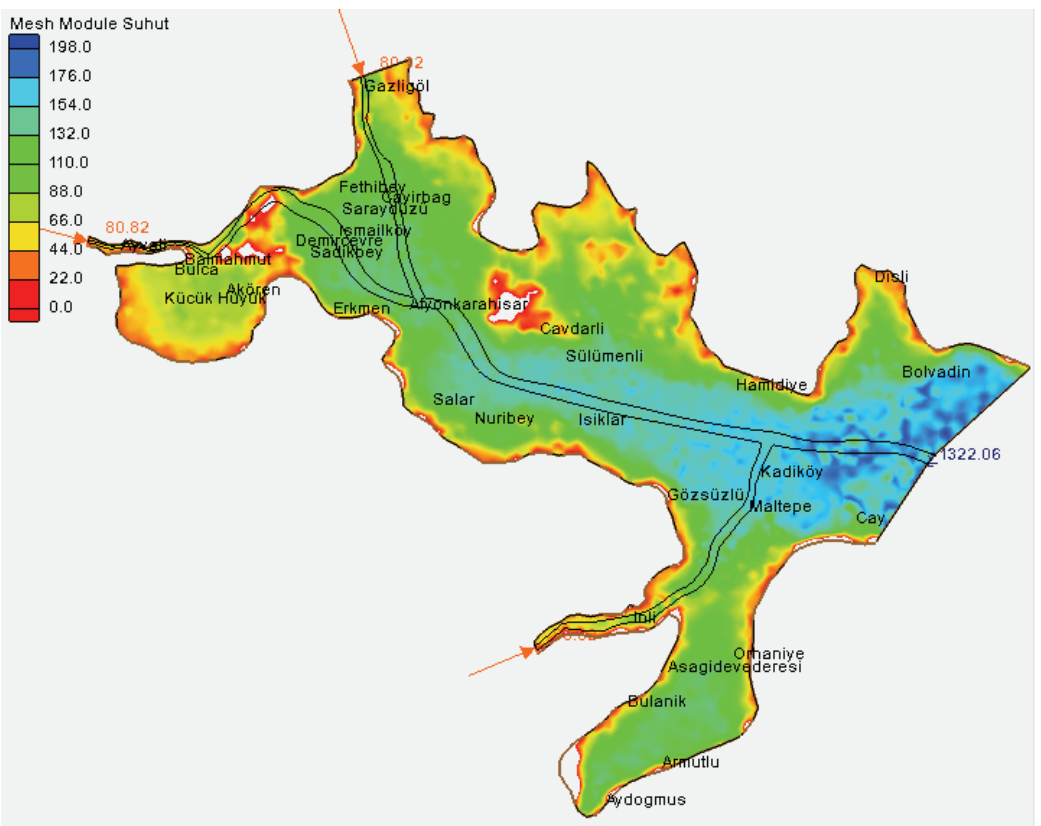

Figure 10 - Flood risk map of the Akarcay Basin in FESWMS model according to altitude of Suhut in threshold 


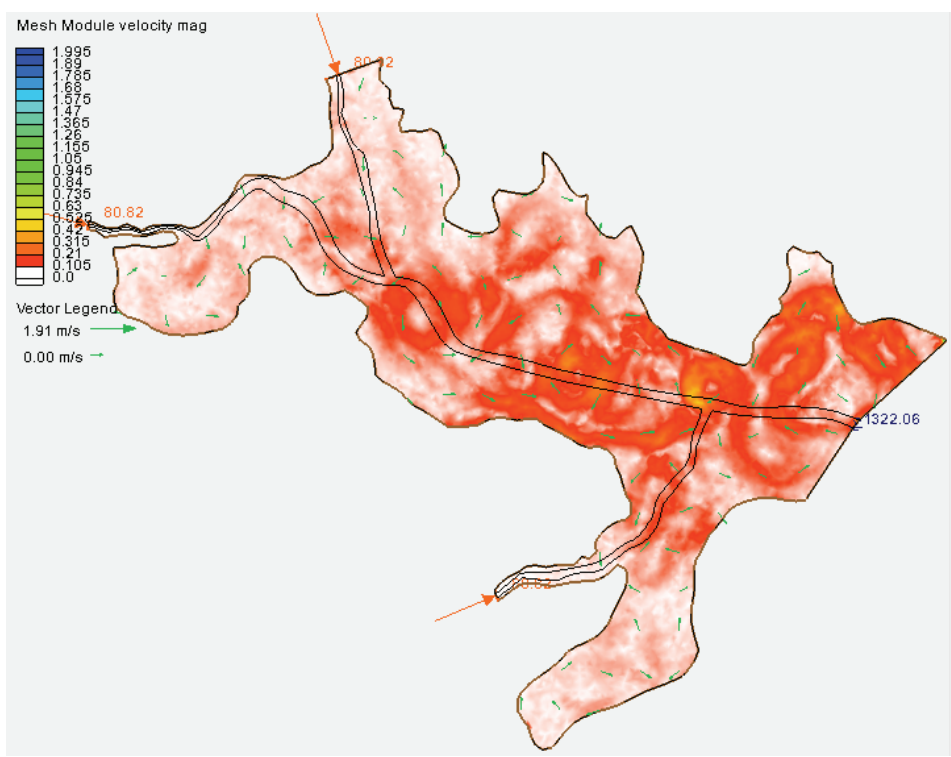

Figure 11 - Flow velocities and magnitudes during the 100-year return period flood event

\subsection{AdH Model}

AdH model uses 3D Navier-Stokes and 2D (depth averaged) shallow water equations. Although 3D models allow a detailed reproduction of flow processes in compound channels, so far, a number of limiting factors usually prevented their application as flood models. The computational burden is still considerably larger for $2 \mathrm{D}$ models, particularly for dynamic shallow flows with significant changes in domain extent. Also, 3D model is preferred for the solution of flow mechanism complexity in urban areas. The ability of AdH to allow the domain to wet and dry as flow conditions or tides change is suitable for shallow marsh environments, floodplains and the like. AdH can simulate subcritical and supercritical flow conditions within the same domain [1]. For overland flow conditions, urban and others were considered. The model was run for 36 and 72 hours at time interval of 1 hour. At the end of computations, flooded area was calculated.

When the parameters which are used in FESWMS model, are also used in the AdH model, flooded areas in the Akarcay Basin are presented in Figure 12. Afyon, Bolvadin and Suhut plains are analyzed separately with AdH model which is used for shallow water modeling. Constant water depth is averagely taken as $0.6 \mathrm{~m}$ by handling observed data. Variable water levels change between 1-3 m. After running the AdH model, the results are manifested in the Google Earth software and the motion of flood waters is followed during the flood event. With these results, the recession of flood waters can be observed. Flood propagation with AdH model is demonstrated by Figures 12-13. The darkness of the blue color indicates the increasing water level. The black lines inside the working area represent the boundaries of the river bed. Flood risk map of Afyonkarahisar City Center from localized AdH model results (Figure 14). The calculated flooded areas from $\mathrm{AdH}$ model are demonstrated in Table 3. 
Flood Analysis Using Adaptive Hydraulics (ADH) Model in the Akarcay Basin

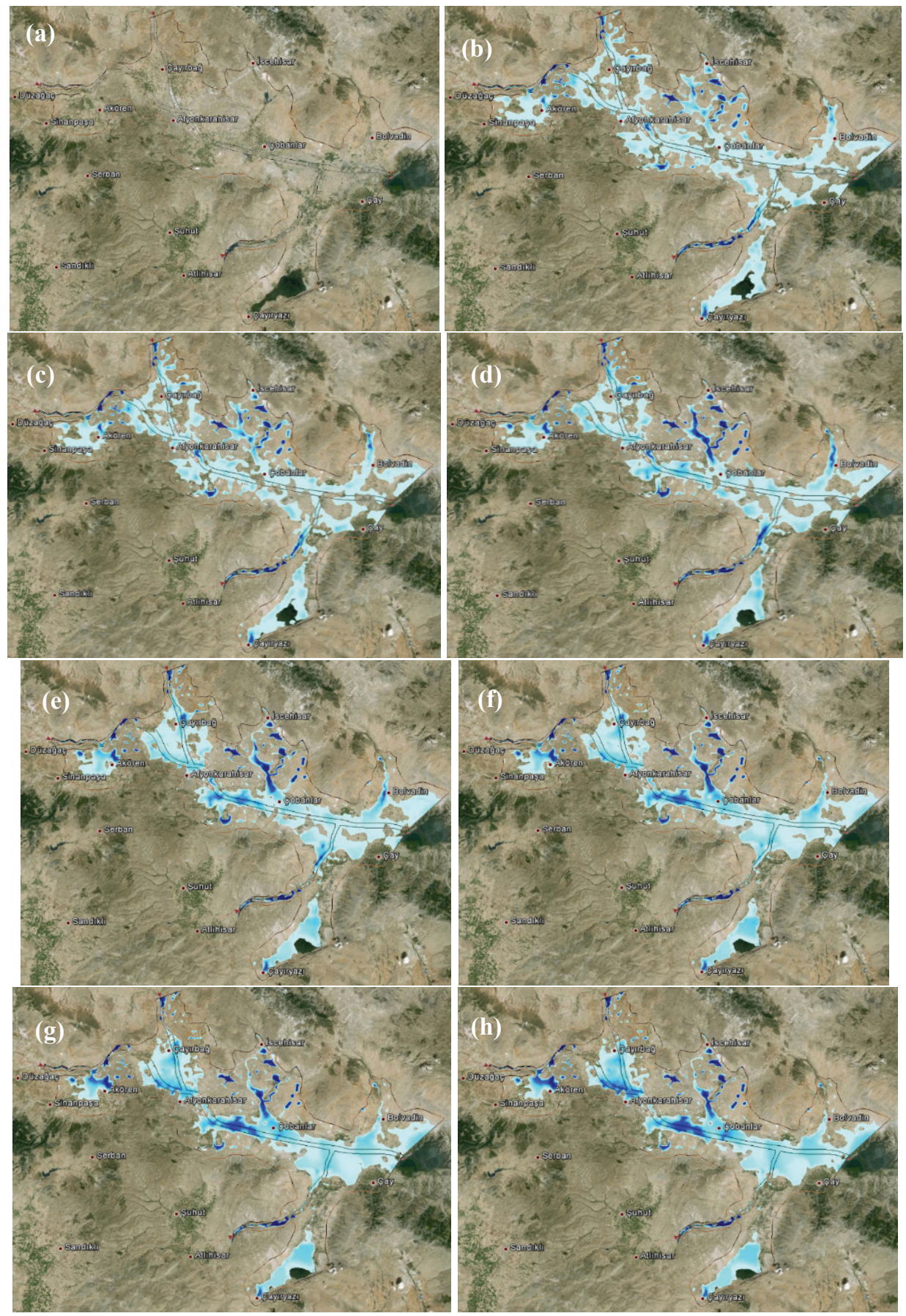

Figure 12 - Flooded areas of Akarcay for different time steps until $72 \mathrm{~h}$ during flood event; (a) $0 \mathrm{~h}$, (b) $12 \mathrm{~h}$, (c) $14 \mathrm{~h}$, (d) $24 \mathrm{~h}$, (e) $36 \mathrm{~h}$, (f) $48 \mathrm{~h}$, (g) $60 \mathrm{~h}$, (h) $72 \mathrm{~h}$ 


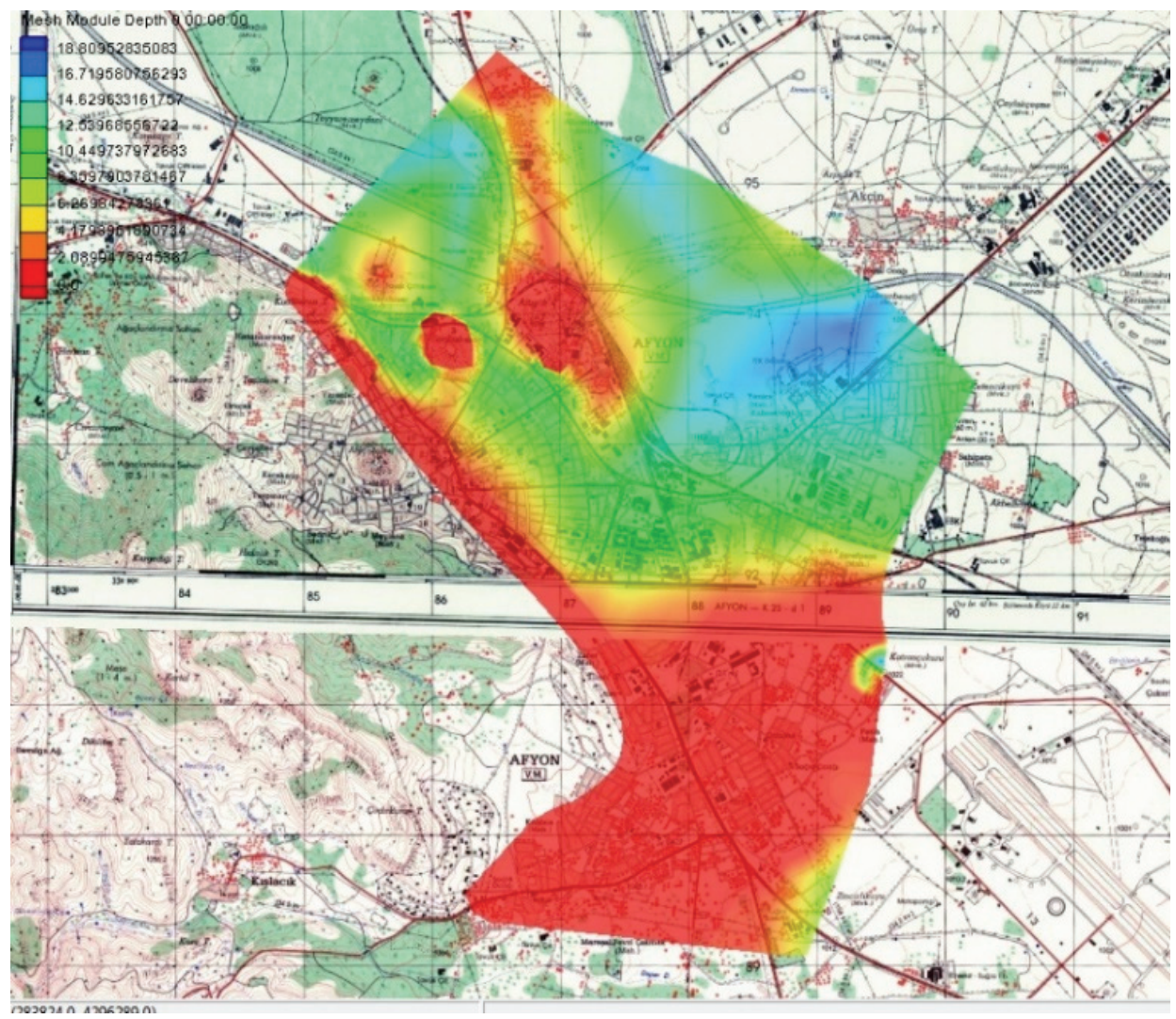

Figure 13 - Flood risk map of Afyonkarahisar City Center from localized AdH model results
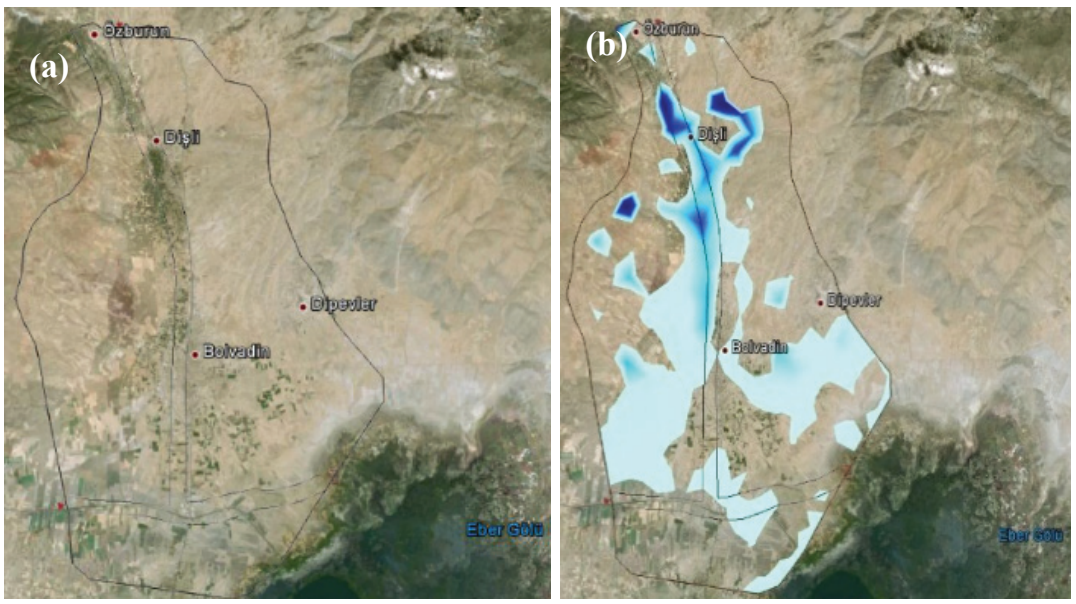
Flood Analysis Using Adaptive Hydraulics (ADH) Model in the Akarcay Basin
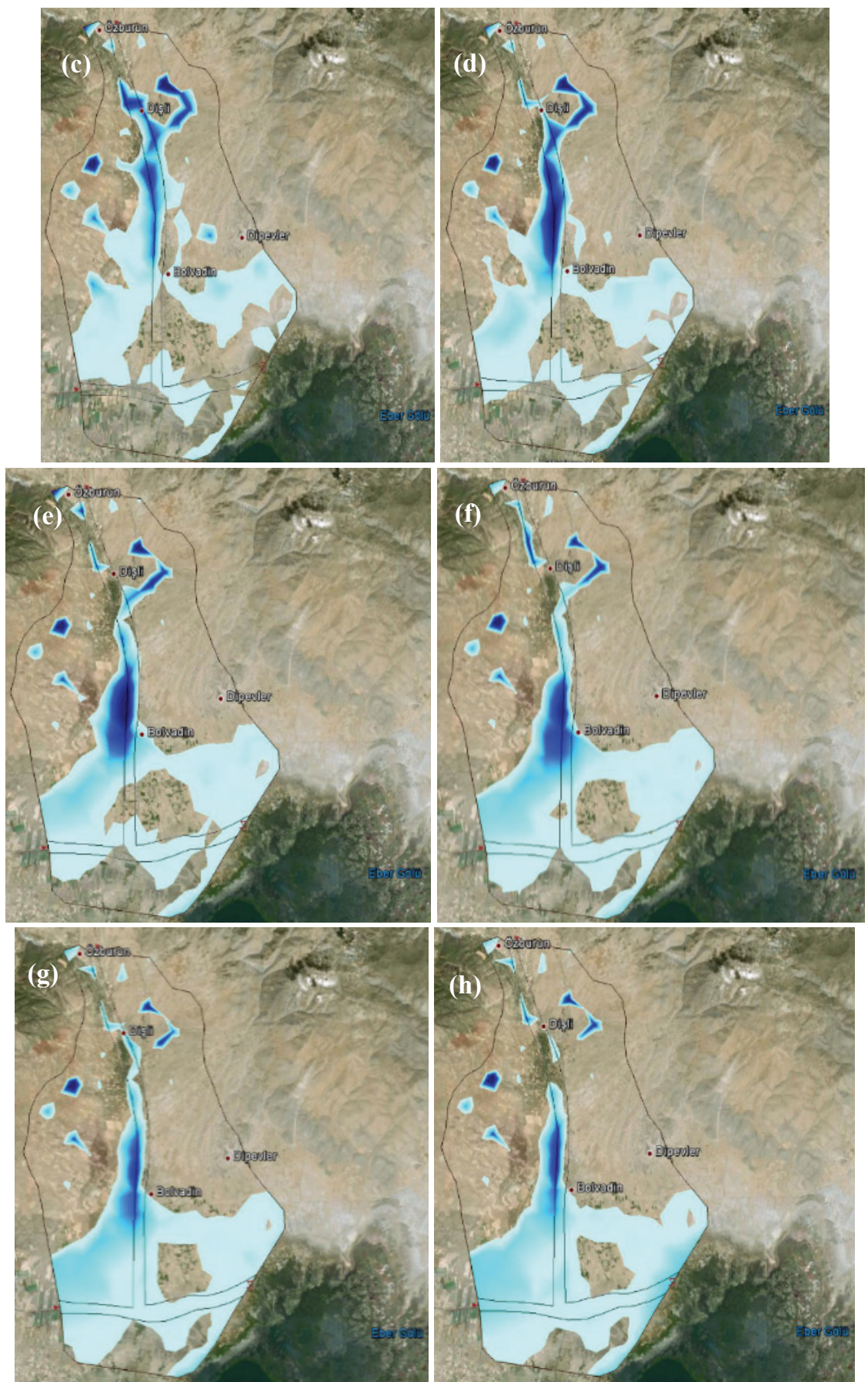

Figure 14 - Flooded areas of Bolvadin near Lake Eber for different time steps until $72 \mathrm{~h}$ during flood event; (a) $0 \mathrm{~h}$, (b) $12 \mathrm{~h}$, (c) $15 \mathrm{~h}$, (d) $24 \mathrm{~h}$, (e) $36 \mathrm{~h}$, (f) $48 \mathrm{~h}$, (g) $60 \mathrm{~h}$, (h) $72 \mathrm{~h}$ 
Table 3 - Flooded areas in the regions of Akarcay Basin for $36 \mathrm{~h}$ and $72 \mathrm{~h}$ simulation time

\begin{tabular}{lll} 
& \multicolumn{2}{c}{ Simulation time $(\mathrm{h})$} \\
\cline { 2 - 3 } Region & \multicolumn{2}{c}{ Area $\left(\mathrm{km}^{2}\right)$} \\
\cline { 2 - 3 } Afyon & 218.65 & 252.60 \\
Bolvadin & 150.81 & 164.21 \\
Suhut & 134.06 & 137.73 \\
Akarcay & 804.72 & 914.83
\end{tabular}

\section{DISCUSSIONS}

In the analyzed models, the changes of the water levels were examined and the areas to be inundated at the time of the flood were calculated. When flood effect caused by a flow rate value of $80.82 \mathrm{~m}^{3} / \mathrm{s}$ worked out by flood analysis results calculated through FESWMS and AdH according to a 100-year return period in the whole of the Akarcay basin and affected settlement areas as well as total areas are taken into consideration.

FESWMS model results:

In the analysis that Afyonkarahisar center gorge is referenced (Figure 7), a total of 503.96 $\mathrm{km}^{2}$ of floods will take place in the Uydukent side, Cayirbag, Sulumenli, Isiklar, Salar, Maltepe, Hamidiye, Kadikoy, Cay and Bolvadin. Bolvadin, Sulumenli, Isiklar, Salar, Maltepe, Hamidiye, Kadikoy, Cay have $422.13 \mathrm{~km}^{2}$ of flood effect in Bolvadin central elevation (Figure 8).

According to Figure 9, the flood effect of reference in the center of the Cay is Afyonkarahisar center, Gazligol, Kucuk Huyuk, Bulca, Balmahmut, Ayvali, Fethibey, Akoren, Cayirbag, Sarayduzu, Ismailkoy, Demircevre, Sadikbey, Erkmen, Nuribey, Cavdarli, Sulumenli, Isiklar, Salar, Maltepe, Hamidiye, Kadikoy, Gozsuzlu, Orhaniye, Asagidevederesi, Disli, Armutlu, Aydogmus, Inli, Bulanik, Cay and Bolvadin. In this analysis, the area under the total flood was found to be $126.16 \mathrm{~km}^{2}$.

It is seen that the water velocity results reach about $0.30 \mathrm{~m} / \mathrm{s}$ values in the plains of Afyon and Bolvadin, and about $0.42 \mathrm{~m} / \mathrm{s}$ in Ihsaniye, Balmahmut and Suhut regions (Figure 11). Moreover, the maximum water velocity at the basin was found to be $1.91 \mathrm{~m} / \mathrm{s}$ for a flow rate of $80.82 \mathrm{~m}^{3} / \mathrm{s}$.

AdH model results:

At the next stage, the water velocities for Akarcay Basin and localized Bolvadin County were obtained according to time steps (Figure 12 and 13). Degirmen Creek which passes through Bolvadin then connects with Akarcay River and together discharge to Lake Eber. Also, Bolvadin is the $3^{\text {rd }}$ largest county with population 43842 people and commercial mobility. After the maximum flood in the outflows obtained, the water velocities in the flood areas decreased and then the overflowing water became almost stagnant 36 and 72 hours.

Flood hydrographs which time interval 1 hours that were calculated through the SCS method 
were applied. The maximum-flooded area was found to be $914.83 \mathrm{~km}^{2}$ at the $14^{\text {th }}$ hour for Akarcay Basin. Also, Afyonkarahisar City Center and Saraycik, Garipce, Fethibey, Erenler, Akcin Counties were affected by flood waters according to peak flood discharge (Figure 12). Flooded area was found to be $761.5 \mathrm{~km}^{2}$ at the end of the $72^{\text {nd }}$ hour for Akarcay Basin along with the regression of flood waters. Again, Afyonkarahisar City Center together with the University Campus and Saraycik, Garipce, Fethibey, Erenler, Akcin Counties were affected by floods. Localized AdH model of flood analysis for Afyonkarahisar City Center was evaluated in Figure 13. It is demonstrated that the places near industrial sites have flood risky areas.

The maximum-flooded area was found to be $164.21 \mathrm{~km}^{2}$ at the $15^{\text {th }}$ hour for Bolvadin Region. The affected areas from flood waters are Bolvadin County Center and Disli Village which is near Bolvadin and in the North of Bolvadin (Figure 14). Flooded area was found to be 114.76 $\mathrm{km}^{2}$ at the end of the $72^{\text {nd }}$ hour for Bolvadin Region along with the retreat of flood waters. Afyon, Bolvadin and Suhut regions have important plains in terms of agriculture and settlements. Akarcay region demonstrates flooded area in the whole basin.

FESWMS model versus AdH model:

The FESWMS module outputs are the change in water velocity and water level in the stream during flood. Akarcay river bed length is about $87 \mathrm{~km}$ and the data entry only at the inlet and exit points in the basin is limitation of the FESWMS model. In addition, the accuracy of the model is variable due to the lack of cross-section identification as in other flood programs.

The ADH module is dynamically operated and the amount of water overflowing the river bed after flood, the areas under water, the changes in water flow rates and water levels can be obtained as output. Due to the dynamic identification of the ADH model, the water heights at the exit point have also changed as compared to the base. But, due to the dynamic setup of the model, the analysis time is longer than the steady-state.

In basin-based analysis, the flood area calculated in the FESWMS module was also obtained by the work done in the ADH module. However, it appears that the fields are not equal, calculated flood areas in the FESWMS module are wider than the field with AdH. This is due to the above limitation of the FESWMS model, so, ADH is expected to provide more accurate results in the Akarcay basin.

\section{CONCLUSIONS}

In order to avoid flood risks, it is necessary to perform flood analysis before the flood and to take necessary precautions to reduce or prevent flood damage. Various flood analysis software has been developed for this purpose. FESWMS and AdH modules of SMS (Surface water Modeling System) software which is one of these softwares were discussed in this work and flood analysis of the Akarcay basin was performed by using modules. Erratic rainfall and discharges as well as impermeable ground, topographic structures increase flood risk at the Akarcay basin. Thus, the measures at stated locations are important in terms of prevention of flood risk. In this study, quite difficult flood calculations were made through computer, this allowing visualization of flooded areas in the 3D form.

For this purpose, FESWMS and AdH models of the SMS software were used. FESMWS 
model was built for the steady state condition and used for calculating peak flood discharges by the four methods mentioned above. The model was run to provide users water velocity and water surface elevation as output. The model was run at one hourly time intervals. AdH model was run under dynamic conditions. Flooded areas, water velocity and water surface elevation are the model outputs there.

The main river reaches $87 \mathrm{~km}$ throughout Akarcay. Maximum water velocity was calculated as $1.91 \mathrm{~m} / \mathrm{s}$. One limitation of FESWMS model is that it only allows data input where there are basin inputs. In addition, the accuracy of the model is variable due to the lack of cross section identification as in other flood modeling programs. According to the ADH model, the FESWMS model predicts that larger areas will be flooded. It is recommended to use the AdH model for precise calculation because of the limited limitations according to FESWMS.

According to results, Erenler, Cayirbag and Fethibey Villages near the University campus are under flood risk. The local population subsist on agriculture and animal husbandry. Also, Sivrikaya Creek passes through University Campus which also has flood risk. Additionally, most of the campus area is marshy land.

With the ease of use of the SMS program interface, it is thought that this work will lead to applications such as flood, sediment transport, multi-directional modeling studies such as water quality and the design of water structures. In addition to hydrological and meteorological data such as rainfall, evaporation, temperature and wind speed results are to be obtained sensitively in the investigated area, the sensitivity of the values can be increased by operating the program on days, hours and minutes basis using digital maps higher than $1 / 25000$ scale. For the first time with the study, hydrodynamic-flood models are developed for Akarcay Basin using FESWMS and AdH models. For future studies, changing earth should be taken into consideration with manmade channels, crowded population and growing settlements, water quality etc. Real time working systems and models are newly developing. After required experimental setups with data observation and data transfer, this type of real time hydrodynamic models can be applied worldwide.

\section{Symbols}

$\begin{array}{ll}A & : \text { Drainage area } \\ A^{\prime} & : \text { The smallest circle area which covers drainage boundary } \\ C N & : \text { Curve Number } \\ D & : \text { Total duration of rainfall } \\ d & : \text { Water depth } \\ g & : \text { Acceleration due to gravity } \\ h_{a} & : \text { Annual rainfall depth of selected return period } \\ h_{e} & : \text { Maximum flow height } \\ L & : \text { Length of drainage channel } \\ P & : \text { Monthly total precipitation }\end{array}$




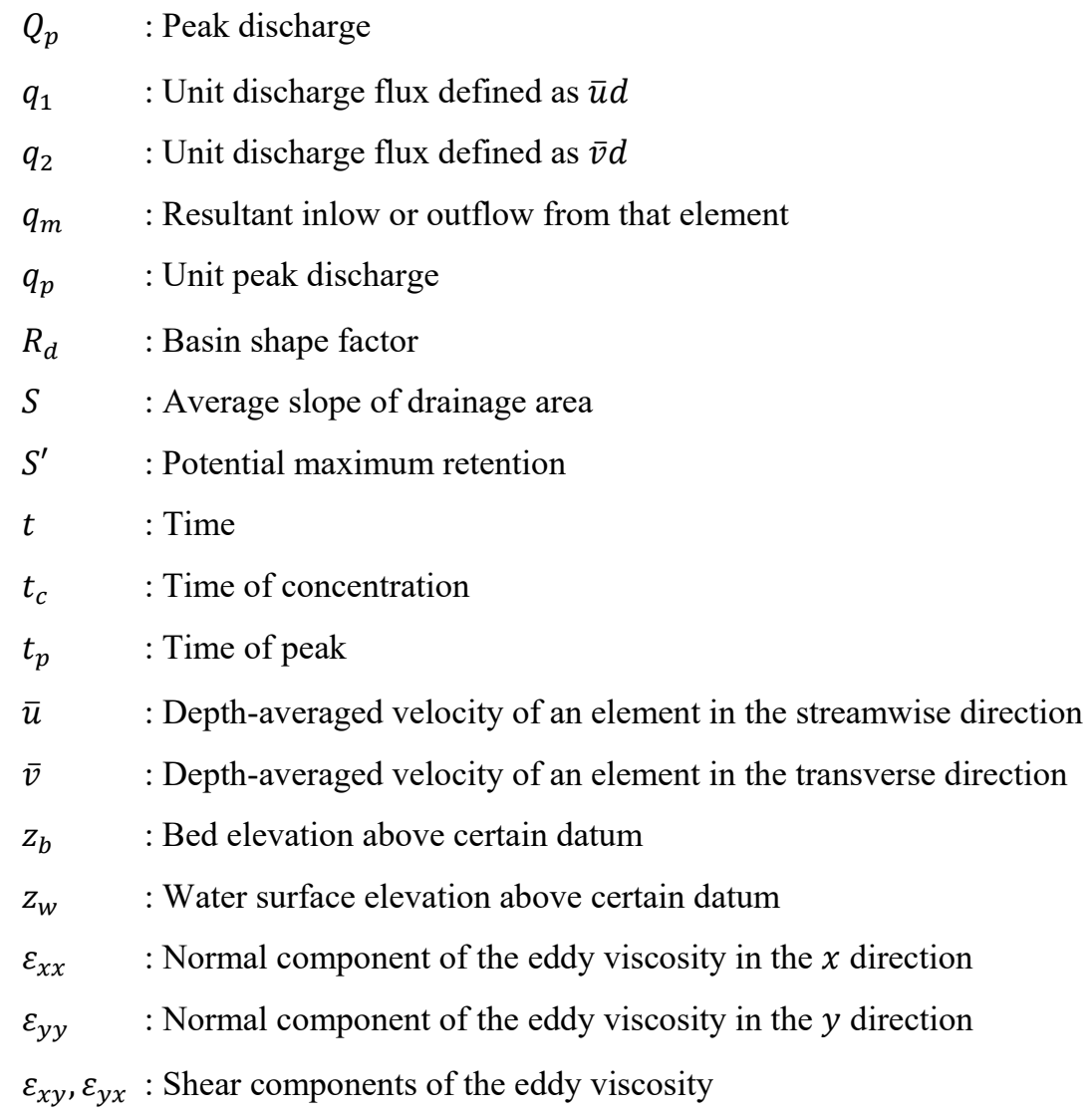

\section{Acknowledgements}

This study is a part of MS thesis of the first author and the study is supported with Scientific Research Project "Flood modelling of Akarcay Basin" (No: 11.FEN.BIL.26) funded by Afyon Kocatepe University.

\section{References}

[1] CHL, Adaptive Hydraulics 2D Shallow Water (AdH- SW2D) User Manual (version 4.6), July 2017, Coastal and Hydraulics Laboratory (CHL), US Army Corps of Engineers (USACE), 2017.

[2] Topaloglu, F., Regional Flood Frequency Analysis of the Basins of the East Mediterranean Region. Turk. J. Agric. For., 29, 287-295, 2005.

[3] Burn, D.H., Evaluation of Regional Flood Frequency Analysis with A Region of Influence Approach. Water Resour. Res., 26(10), 2257-2265, 1990. 
[4] Burn, D.H., An Appraisal of The "Region of Influence" Approach to Flood Frequency Analysis. Hydrolog. Sci. J., 35(2), 149-165, 1990.

[5] Burn, D.H., Catchment Similarity for Regional Flood Frequency Analysis Using Seasonality Measures. J. Hydrol., 202, 212-230, 1997.

[6] Rossi, F., Fiorentino, M., Versace, P., Two-Component Extreme Value Distribution for Flood Frequency Analysis. Water Resour. Res., 20(7), 847-856, 1984.

[7] Stedinger, J.R., Cohn, T.A., Flood Frequency Analysis with Historical and Paleoflood Information. Water Resour. Res., 22(5), 785-793, 1987.

[8] Zhang, L., Singh, V.P., Bivariate Flood Frequency Analysis Using the Copula Method. J. Hydrol. Eng., 11(2), 150-164, 2006.

[9] Grimaldi, S., Serinaldi, F., Asymmetric Copula in Multivariate Flood Frequency Analysis. Adv. Water Resour., 29, 1155-1167, 2006.

[10] Yue, S., Ouarda, T.B.M.J., Bobee, B., Legendre, P., Bruneau, P., The Gumbel Mixed Model for Flood Frequency Analysis. J. Hydrol., 226, 88-100, 1999.

[11] Acreman, M.C., Sinclair, C.D., Classification of Drainage Basins According to Their Physical Characteristics; An Application for Flood Frequency Analysis in Scotland. J. Hydrol., 84, 365-380, 1986.

[12] Bates, P.D., De Roo, A.P.J., A Simple Raster-Based Model for Flood Inundation Simulation. J. Hydrol., 236, 54-77, 2000.

[13] Horritt, M.S., Bates, P.D., Evaluation of 1D and 2D Numerical Models for Predicting River Flood Inundation. J. Hydrol., 268, 87-99, 2002.

[14] Sanders, B.F., Evaluation of On-line DEMs for Flood Inundation Modeling. Adv. Water Resour., 30, 1831-1843, 2007.

[15] Yamazaki, D., Ikeshima, D., Tawatari, R., Yamaguchi, T., O’Loughlin, F., Neal, J.C., Sampson, C.C., Kanae, S., Bates, P.D., A High-Accuracy Map of Global Terrain Elevations. Geophys. Res. Lett., 44, 5844-5853, 2017.

[16] Ciervo, F., Papa, M.N., Medina, V., Bateman, A., Simulation of Flash Floods in Ungauged Basins Using Post-Event Surveys and Numerical Modelling. J. Flood Risk Manag., 8, 343-355, 2015.

[17] Bradford, S.F., Sanders, B.F., Finite-Volume Model for Shallow-Water Flooding of Arbitrary Topography. J. Hydraul. Eng., 128(3), 289-298, 2002.

[18] de Almeida, G.A.M., Bates, P., Ozdemir, H., Modelling Urban floods at Submetre Resolution: Challenges or Opportunities for flood Risk Management? J. Flood Risk Manag., https://doi.org/10.1111/jfr3.12276, 2016.

[19] Falter, D., Dung, N.V., Vorogushyn, S., Schroter, K., Hundecha, Y., Kreibich, H., Apel, H., Theisselmann, F., Merz, B., Continuous, Large-Scale Simulation Model for Flood Risk Assessments: Proof-Of-Concept. J. Flood Risk Manag., 9, 3-21, 2016.

[20] Papanicolaou, A.N., Elhakeem, M., Wardman, B., Calibration and Verification of A 
2D Hydrodynamic Model for Simulating Flow Around Emergent Bendway Weir Structures. J. Hydraul. Eng., 137(1), 75-89, 2011.

[21] Rossell, R.P., Ting, F.C.K., Hydraulic and Contraction Scour Analysis of A Meandering Channel: James River Bridges Near Mitchell, South Dakota. J. Hydraul. Eng., 139(12), 1286-1296, 2013.

[22] Larsen, R.J., Ting, F.C.K., Jones, A.L., Flow Velocity and Pier Scour Prediction in a Compound Channel: Big Sioux River Bridge at Flandreau, South Dakota. J. Hydraul. Eng., 137(5), 595-605, 2011.

[23] Cook, A. Merwade, V., Effect of Topographic Data, Geometric Configuration and Modeling Approach on Flood Inundation Mapping. J. Hydrol., 377, 131-142, 2009.

[24] Pasternack, G.B., Bounrisavong, M.K., Parikh, K.K., Backwater Control on RifflePool Hydraulics, Fish Habitat Quality, And Sediment Transport Regime in Gravel-Bed Rivers. J. Hydrol., 357, 125-139, 2008.

[25] Brown, R.A., Pasternack, G.B., Engineered Channel Controls Limiting Spawning Habitat Rehabilitation Success on Regulated Gravel-Bed Rivers. Geomorphology, 97, 631-654, 2008.

[26] Brown, R.A., Pasternack, G.B., Comparison of Methods for Analysing Salmon Habitat Rehabilitation Designs for Regulated Rivers. River Res. Appl., 25, 745-772, 2009.

[27] Cavagnaro, P., Revelli, R., Numerical Model Application for the Restoration of the Racconigi Royal Park (CN, Italy). J Cult. Herit., 10, 514-519, 2009.

[28] Jennings, A.A., Modeling Sedimentation and Scour in Small Urban Lakes. Environ. Modell. Softw., 18, 281-291, 2003.

[29] Mouton, A.M., Schneider, M., Peter, A., Holzer, G., Muller, R., Goethals, P.L.M., Pauw, N.D., Optimisation of A Fuzzy Physical Habitat Model for Spawning European Grayling (Thymallus Thymallus L.) in the Aare River (Thun, Switzerland). Ecol. Model., 215, 122-132, 2008.

[30] Zanichelli, G., Caroni, E., Fiorotto, V., River Bifurcation Analysis by Physical and Numerical Modeling. J. Hydraul. Eng., 130(3), 237-242, 2004.

[31] Stockstill, R.L., Daly, S.F., Hopkins, M.A., Modeling Floating Objects at River Structures. J. Hydraul. Eng., 135(5), 403-414., 2009.

[32] Sharp, J.A., McAnally, W.H., Numerical Modeling of Surge Overtopping of A Levee. Appl. Math. Model., 36, 1359-1370, 2012.

[33] Jones, L., Adaptive Control of Ground-Water Hydraulics. J. Water Res. Plan. Man., 118(1), 1-17, 1992.

[34] Danchuk, S., Willson, C.S., Effects of Shoreline Sensitivity on Oil Spill Trajectory Modeling of the Lower Mississippi River. Environ. Sci. Pollut. R., 17, 331-340, 2010.

[35] Lai, X., Jiang, J., Liang, Q., Huang, Q., Large-Scale Hydrodynamic Modeling of the Middle Yangtze River Basin with Complex River-Lake Interactions. J. Hydrol., 492, 228-243, 2013. 
[36] Martin, S.K., Savant, G., McVan, D.C., Two-Dimensional Numerical Model of the Gulf Intracoastal Waterway near New Orleans. J. Waterw. Port Coast., 138(3), 236245, 2012.

[37] McAlpin, T.O., Sharp, J.A., Scott, S.H., Savant, G., Habitat Restoration and Flood Control Protection in the Kissimmee River. Wetlands, 33, 551-560, 2013.

[38] Nguyen, H.V., Cheng, J.C., Hammack, E.A., Maier, R.S., Parallel Newton-Krylov Solvers for Modeling of A Navigation Lock Filling System. Procedia Computer Science, 1, 699-707, 2012.

[39] Nguyen, H.V., Cheng, J.C., Berger, C.R., Savant, G., A Mass Conservation Algorithm for Adaptive Unrefinement Meshes Used by Finite Element Methods. Procedia Computer Science, 9, 727-736, 2012.

[40] Eller, P.R., Cheng, J.C., Maier, R.S., Dynamic Linear Solver Selection for Transient Simulations Using Multi-Label Classifiers. Procedia Computer Science, 9, 1523-1532, 2012.

[41] Pettway, J.S., Schmidt, J.H., Stagg, A.K., Adaptive Meshing in A Mixed Regime Hydrologic Simulation Model. Computat. Geosci., 14, 665-674, 2010.

[42] Savant, G., Berger, C., McAlpin, T.O., Tate, J.N., Efficient Implicit Finite-Element Hydrodynamic Model for Dam and Levee Breach. J. Hydraul. Eng., 137(9), 1005-1018, 2011.

[43] Burgan, H.I., Flood Modelling of Akarcay Basin. MS Thesis, Afyon Kocatepe University, 2013.

[44] Chow, V.T., Open-channel Hydraulics. New York: McGraw-Hill, 1959. 
